\title{
MOLECULAR STRUCTURE INVESTIGATION OF Z-3N(2-ETHOXYPHENYL)-2-N'(2-ETHOXYPHENYL)-IMINO-THIAZOLIDIN-4-ONE BY AB INITIO, DFT AND X-RAY DIFFRACTION METHODS
}

\author{
M. Boulakoud ${ }^{1}$, K. Toubal ${ }^{2}$, S. Yahiaoui ${ }^{1}$, A. Chouaih ${ }^{1}$, G. Chita $^{3}$, A. Djafri ${ }^{2}$, F. Hamzaoui ${ }^{1}$ \\ ${ }^{1}$ Laboratoire de Technologie et Propriétés des Solides, Faculté des Sciences et de la Technologie, University \\ Abdelhamid Ibn Badis of Mostaganem, 27000 Mostaganem, Algeria \\ E-mail: achouaih@gmail.com \\ ${ }^{2}$ Laboratoire de Synthèse Organique Appliquée (LSOA), Département de Chimie, Faculté de Sciences, University \\ of Oran-Es-Sénia, 31000 Oran, Algeria \\ ${ }^{3}$ CNR-IC Institute of Crystallography, Via Amendola 122/O, 70126 Bari, Italy
}

\begin{abstract}
We report here the synthesis of the Z-3N(2-ethoxyphenyl)-2-N'(2-ethoxyphenyl)-iminothiazolidin-4-one compound. The crystal structure is determined by X-ray diffraction. The compound crystallizes in the monoclinic system with the space group $P 2_{1} / n$ and cell parameters: $a=9.4094(10) \AA, b=9.3066(10) \AA, c=20.960(2) \AA, \beta=99.0375(10)^{\circ}, V=1812.7(3) \AA^{3}$ and $Z=4$. The structure is refined to final $R=0.05$ for 2083 observed reflections. The molecule in the crystal exhibits the intermolecular hydrogen bonds of $\mathrm{C}-\mathrm{H} \ldots \mathrm{O}, \mathrm{C}-\mathrm{H} \ldots \mathrm{N}$, and $\mathrm{C}-\mathrm{H}$...S types. Ab initio calculations are also performed at Hartree-Fock (HF) and density functional theory (DFT) levels. The full HF and DFT geometry optimization is carried out using the $6-31 \mathrm{G}(d, p)$ basis set. The observed molecular structure is compared with that calculated by both HF and DFT methods. The optimized geometry of the titled compound is found to be consistent with the structure determined by X-ray diffraction.
\end{abstract}

\section{DOI: $10.15372 / J S C 20150719$}

K e y w o r d s: synthesis, structure, X-ray diffraction, thiazolidin-4-one, theoretical calculations, organic compounds.

\section{INTRODUCTION}

Thiazoles are an important class of heterocyclic compounds. The thiazole moiety belongs to an important class of $\mathrm{N}$ - and S-containing heterocycles. This heterocyclic system is responsible for a broad spectrum of biological activities. There are numerous studies of simple thiazoles, reporting their biological activity [ $1-6]$. Due to their properties, thiazole derivatives are interesting candidates for obtaining new materials. Thiazole compounds have also been studied for their nonlinear optical properties $[7,8]$.

Prompted by these investigations and in continuation of our search on the development of organic heterocyclic compounds $[9,10]$, in this paper we report the synthesis and crystal structure of compound I, Z-3N(2-ethoxyphenyl)-2-N'(2-ethoxyphenyl)-imino-thiazolidin-4-one $\mathrm{C}_{19} \mathrm{H}_{20} \mathrm{~N}_{2} \mathrm{O}_{3} \mathrm{~S}$ (Fig. 2) and compare the observed molecular geometries with those optimized by density functional theory (DFT) and Hartree-Fock methods.

(C) Boulakoud M., Toubal K., Yahiaoui S., Chouaih A., Chita G., Djafri A., Hamzaoui F., 2015 
<smiles></smiles>

$a$<smiles>[H][Z13]([H])(C)Oc1ccccc1N1C(=O)CSC1=S</smiles>

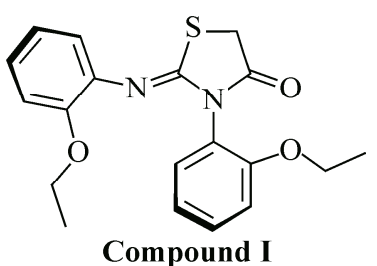

Fig. 1. Preparation and chemical structure of Z-3N(2-ethoxyphenyl)-2-N'(2-ethoxyphenyl)-imino-thiazolidin-4one (compound I)

\section{EXPERIMENTAL AND COMPUTATIONAL METHODS}

Synthesis. Compound I was prepared by the reaction of S-methyl iodide, 4-Me-3-N (o-ethyl phenyl) $\Delta^{4}$ thiazolium $(0.01 \mathrm{~mol}), 2$-thioxo-3-N'(2-ethoxyphenyl thiazolidine)-4-one (0.01 mol), $20 \mathrm{ml}$ of acetone in a $150 \mathrm{ml}$ boiling flask. Then $2 \mathrm{ml}$ of triethylamine were added to this mixture. The system was refluxed for 24 hours at ambient temperature, forming a yellow solid. The crystals obtained were filtered and recrystallized in acetone. Fig. 1 shows the preparation and chemical structure of compound I and its photodegradation by UV-visible light leading to the studied molecule (compound I).

Spectral analysis. All reagents and solvents for the synthesis and spectroscopic studies were commercially available and used as received without further purification. The IR spectra were mesured on a JASCO 4200 FT-IR spectrometer as a $\mathrm{KBr}$ pellet. The ${ }^{1} \mathrm{H}$ and ${ }^{13} \mathrm{C}$ NMR spectra were measured in $\mathrm{CDCl}_{3}$ on a BRUKER Ac DPX-200 (300 MHZ) spectrometer at $25^{\circ} \mathrm{C}$.

Spectral data. Yellow solid, yield $78 \%$, m.p. $210^{\circ} \mathrm{C}, \mathrm{IR}\left(\mathrm{KBr}, \mathrm{cm}^{-1}\right): 3407$ broad band, 3035 $(\mathrm{C}-\mathrm{N}), 1710(\mathrm{C}=\mathrm{O}), 1256(\mathrm{C}-\mathrm{S})$.

$\mathrm{H}^{1} \mathrm{NMR},\left(\mathrm{CDCl}_{3}, 300 \mathrm{MHz}\right) \delta(\mathrm{ppm}) \mathrm{J}(\mathrm{HZ}): 1.276(\mathrm{t}, 3 \mathrm{H},-\mathrm{O}-\mathrm{CH} 2-\mathrm{CH} 3$ thione $), 1.930$ $(\mathrm{t}, 3 \mathrm{H},-\mathrm{O}-\mathrm{CH} 2-\mathrm{CH} 3$, thiazolidène $) ; 1.930(\mathrm{~s}, 3 \mathrm{H}, \mathrm{Me}$ thia, $J=1.06) ; 4.031(\mathrm{q}, 2 \mathrm{H},-\mathrm{O}-\mathrm{CH} 2-$ $\mathrm{CH}_{3}$ thione); 4.135(q, 2H, $-\mathrm{O}-\mathrm{CH} 2-\mathrm{CH} 3$ thiazolidène); $6.34(\mathrm{~s}, 1 \mathrm{H}, J=1.06) ; 7.621-7.023(\mathrm{~m}$, $8 \mathrm{H}$ aryle).

$\mathrm{C}^{13} \mathrm{NMR},\left(\mathrm{CDCl}_{3}, 300 \mathrm{MHz}\right) \delta(\mathrm{ppm}): 8.65(\mathrm{O}-\mathrm{CH} 2-\mathrm{CH} 3) ; 14.76\left(\mathrm{Me}_{4}\right) ; 56.14\left(\mathrm{C}\right.$ thia- $\left.\mathrm{Me}_{4}\right) ;$ $64.43(-\mathrm{O}-\mathrm{CH} 2-\mathrm{CH} 3) ; 112.80 ; 113.63 ; 120.83 ; 121.41 ; 123.57 ; 125.40 ; 130.02 ; 130.63 ; 137.81$; $129.99\left(\mathrm{C}\right.$ thia- $\left.-\mathrm{Me}_{4}\right) ; 133.29\left(\mathrm{C}\right.$ thia- $\left.\mathrm{H}_{5}\right) ; 103.48(\mathrm{C}=\mathrm{C}) ; 154.63(\mathrm{C}=\mathrm{C}) ; 155.86(\mathrm{C}-\mathrm{S}) ; 189.52(\mathrm{C}=\mathrm{O})$.

$\mathrm{X}$-ray structure determination. A yellow prismatic crystal with approximate dimensions of $0.20 \times 0.15 \times 0.10 \mathrm{~mm}$ was selected for data collection. The X-ray diffraction data were collected on a Kappa CCD Bruker-Nonius diffractometer. The SHELX program [11] was used for the structure solution and refinement. The structure was solved by direct methods. A Fourier synthesis revealed the complete structure, which was refined by the full-matrix least squares technique. All non-H atoms

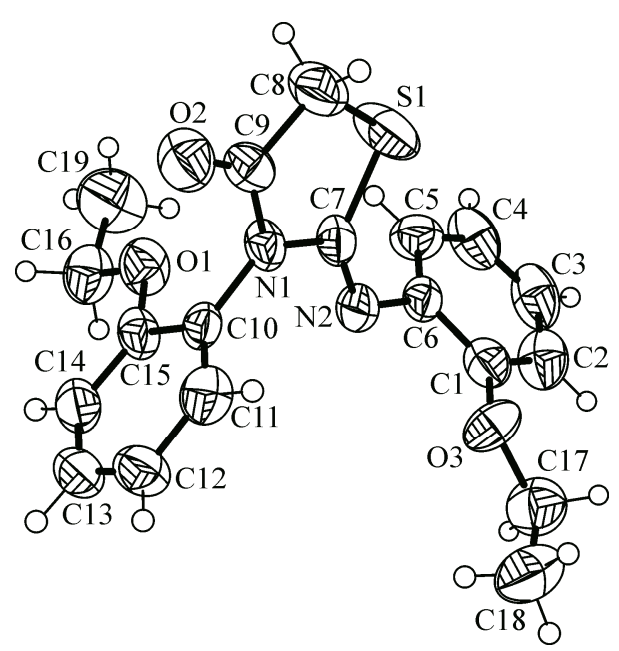
were refined anisotropically. The positions of $\mathrm{H}$ atoms bonded to $\mathrm{C}$ atoms were calculated. An ORTEP [ 12] view of the molecular structure with the atomic numbering is shown in Fig. 2. Atomic scattering factors for heavy atoms were taken from International Tables for X-ray Crystallography [13 ] while the factors for $\mathrm{H}$ were those of Stewart, Davidson, and Simpson [ 14 ]. The details of the crystal data and refinement: $\mathrm{C}_{19} \mathrm{H}_{20} \mathrm{~N}_{2} \mathrm{O}_{3} \mathrm{~S}, M=356.44, T=294(2) \mathrm{K}$, monoclinic, space group $P 2{ }_{1} / n, \quad a=9.4094(10), \quad b=9.3066(10), \quad c=$ $=20.960(2) \AA, \quad \beta=99.0375(10)^{\circ}, \quad V={ }^{\circ} 1812.7(3)^{\circ} \AA^{3}, \quad \lambda=$

Fig. 2. General view of the molecule (compound I) with the atomic numbering scheme (thermal ellipsoids drawn at a $50 \%$ probability). $\mathrm{H}$ atoms are shown as small spheres of arbitrary radii 
Fig. 3. A perspective view of the crystal packing in the unit cell

$=0.71073 \AA, Z=4, d_{\mathrm{c}}=1.303 \mathrm{mg} / \mathrm{m}^{3}, F(000)=752, \theta$ range $5.02-27.51^{\circ}$, index ranges $-12 \leq h \leq 12,-10 \leq k \leq 12,-27 \leq$ $\leq l \leq 27,4141$ reflections collected, 2083 observed $(I \geq 2 \sigma(I))$, 229 parameters, final $R_{1}=0.0504, w R_{2}=0.1601$, GOOF $=$ $=0.855$ (observed), $R_{1}=0.3535, w R_{2}=0.1607 \quad$ (all data), CCDC 989101.

Computational method. Theoretical calculation methods are presently considered to be one of the most successful models in the world of computational chemistry since it yields accurate results for several physicochemical properties. For calculations involving hydrogen bonding interaction systems it

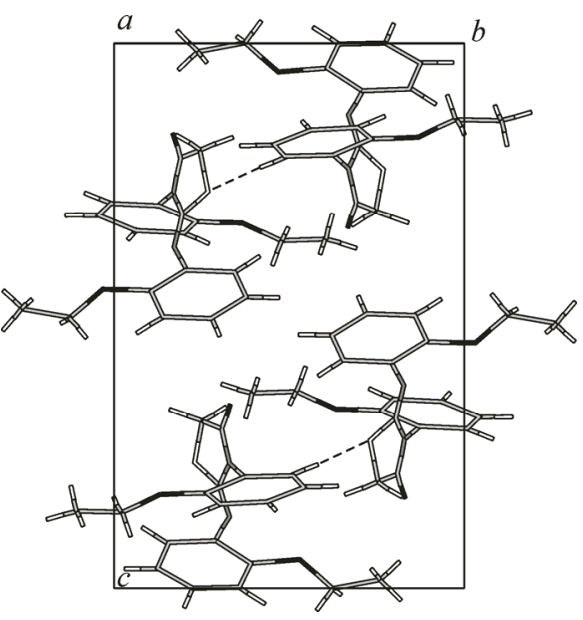
is very important to select an appropriate method and carefully consider and evaluate the accuracy and speed of the calculation. DFT methods are fast and can be used to compute mid-sized and even large molecular systems. In this work, the full geometry optimization has been performed using the GAUSSIAN03 package [15] and the Gauss-View molecular visualization program [16] with the Becke 3-parameter hybrid exchange functions and the Lee-Young-Parr correlation functional (B3LYP) [17, 18 ] and HF theory [19], using the 6-31G $(d, p)$ basis set by the Berny method [20,21].

\section{RESULTS AND DISCUSSION}

Crystal structure description. The molecular structure of compound I with atomic labeling (thermal ellipsoids are drawn at a $50 \%$ probability) is shown in Fig. 2. Fig. 3 shows a perspective view of the crystal packing in the unit cell. Selected bond lengths, bond and torsion angles for all nonhydrogen atoms determined by X-ray diffraction are listed in Table 1, together with the calculated parameters, respectively. The average values of bond distances and angles in the two benzene rings for both experimental and calculated data are in good agreement with the literature values. The two $\mathrm{C}-\mathrm{S}$ distances ( $\mathrm{S} 1-\mathrm{C} 7$ and $\mathrm{S} 1-\mathrm{C} 8$ of $1.756(6) \AA$ and $1.779(6) \AA$, respectively) in the thiazole ring have the values intermediate between those reported for single $(1.81 \AA)$ and double $(1.61 \AA)$ bonds [ 14 ]. The $\mathrm{C} 9-\mathrm{O} 2$ bonds show a typical double bond character with a bond length of 1.204(7) $\AA$. All of the $\mathrm{C}-\mathrm{N}$ bonds $\quad(\mathrm{C} 6-\mathrm{N} 2=1.414(7) \AA, \quad \mathrm{C} 7-\mathrm{N} 1=1.382(6) \AA, \quad \mathrm{C} 9-\mathrm{N} 1=1.369(7) \AA, \quad \mathrm{C} 10-\mathrm{N} 1=$ $=1.454(6) \AA)$ also indicate a partial double bond character. The double bond $\mathrm{C} 7-\mathrm{N} 2=1.255(6) \AA$ is slightly shorter than the other $\mathrm{C}-\mathrm{N}$ bonds. The fragment formed by $\mathrm{O} 2, \mathrm{C} 9, \mathrm{~N} 1, \mathrm{C} 7$, and $\mathrm{N} 2$ atoms is a conjugated system with the delocalization of $\pi$ electron densities. This conjugated system is responsible for the charge transfer within the molecule.

The mean value of bond angles in the thiazole ring is $107.81(2)^{\circ}$. In the rest of the molecule, all bond angles $(\mathrm{C}-\mathrm{C}-\mathrm{C}, \mathrm{C}-\mathrm{N}-\mathrm{C}$, and $\mathrm{C}-\mathrm{C}-\mathrm{N}, \ldots)$ are close to $120^{\circ}$, indicating that the $\pi$ electrons are delocalized in the titled compound. The torsion angles $\mathrm{C} 7-\mathrm{N} 1-\mathrm{C} 9-\mathrm{C} 8\left(0.8(7)^{\circ}\right)$, $\mathrm{C} 7-\mathrm{S} 1-\mathrm{C} 8-\mathrm{C} 9\left(-3.5(5)^{\circ}\right), \mathrm{S} 1-\mathrm{C} 8-\mathrm{C} 9-\mathrm{O} 2\left(-177.8(5)^{\circ}\right)$, and $\mathrm{S} 1-\mathrm{C} 8-\mathrm{C} 9-\mathrm{N} 1\left(2.2(6)^{\circ}\right)$ indicate that the five-membered heterocycle has a planar conformation.

Geometry optimization. The ground state geometries were optimized at the Hartree Fock and DFT levels of theory, using the $6-31 \mathrm{G}(d, p)$ basis set. The optimized structure of the titled compound is illustrated in Fig. 4 and the corresponding main geometrical parameters (bond lengths, bond and tor sion angles) are listed in Tables 1. As we can see there is good agreement between the calculated and the experimental values. The

Fig. 4. Theoretical crystal structure of the titled compound at the B3LYP/6$31 \mathrm{G}(d, p)$ level

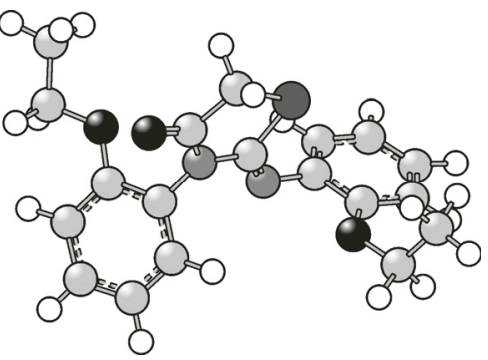


Bond distances, bond angles and torsion angles for non-hydrogen atoms from X-ray diffraction measurements and theoretical calculations (e.s.d. are given in parenthesis)

\begin{tabular}{|c|c|c|c|c|c|c|c|}
\hline \multirow{2}{*}{$\begin{array}{l}\text { Bond distances, } \AA \\
\text { Bond angles, deg. }\end{array}$} & \multirow{2}{*}{ T-ray } & \multicolumn{2}{|c|}{$6-31 \mathrm{G}(d, p)$} & \multirow{2}{*}{$\begin{array}{l}\text { Bond torsion } \\
\text { angles, deg. }\end{array}$} & \multirow{2}{*}{$\mathrm{X}$-ray } & \multicolumn{2}{|c|}{$6-31 \mathrm{G}(d, p)$} \\
\hline & & $\mathrm{HF}$ & B3LYP & & & $\mathrm{HF}$ & B3LYP \\
\hline . & ) & 781 & 1.801 & $17-\mathrm{O} 3-\mathrm{C} 1-\mathrm{C} 2$ & $-22.3(8)$ & 0.23 & 2.74 \\
\hline $\mathrm{S} 1-\mathrm{C} 8$ & & 1.807 & 1.827 & $17-\mathrm{O} 3-\mathrm{C} 1-\mathrm{C} 6$ & & 179.9 & -178.1 \\
\hline $\mathrm{N} 1-\mathrm{C} 9$ & $69(7)$ & 1.372 & 1.390 & $3-\mathrm{C} 1-\mathrm{C} 2-\mathrm{C} 3$ & (5) & 179.3 & 178.8 \\
\hline $\mathrm{N} 1-\mathrm{C} 7$ & $82(6)$ & 1.391 & 1.402 & $4-\mathrm{C} 5-\mathrm{C} 6-\mathrm{N} 2$ & & -176.4 & -175.6 \\
\hline $\mathrm{N} 1-\mathrm{C} 10$ & $54(6)$ & 1.428 & 1.433 & $3-\mathrm{C} 1-\mathrm{C} 6-\mathrm{C} 5$ & $(5)$ & -178.8 & -178.3 \\
\hline $\mathrm{O} 1-\mathrm{C} 15$ & $53(6)$ & 1.343 & 1.357 & $\mathrm{O} 3-\mathrm{C} 1-\mathrm{C} 6-\mathrm{N} 2$ & $-7.0(7)$ & -3.5 & -3.7 \\
\hline $\mathrm{O} 1-\mathrm{C} 16$ & $428(6)$ & 1.408 & 1.429 & $2-\mathrm{C} 1-\mathrm{C} 6-\mathrm{N} 2$ & & 176.2 & 175.4 \\
\hline $\mathrm{O} 2-\mathrm{C} 9$ & $4(7)$ & 1.188 & 12 & $\mathrm{C} 5-\mathrm{C} 6-\mathrm{N} 2-\mathrm{C} 7$ & 8) & -98.3 & -100.8 \\
\hline $\mathrm{O} 3-\mathrm{C} 1$ & (7) & 1.350 & 1.368 & $1-\mathrm{C} 6-\mathrm{N} 2-\mathrm{C} 7$ & (6) & 86.3 & 84.6 \\
\hline $\mathrm{O} 3-\mathrm{C} 17$ & (7) & 1.407 & 1.428 & $6-\mathrm{N} 2-\mathrm{C} 7-\mathrm{N} 1$ & (5) & -179.2 & -177.4 \\
\hline $\mathrm{C} 6$ & & 1.409 & 09 & $5-\mathrm{N} 2-\mathrm{C} 7-\mathrm{S} 1$ & & 0.7 & 2.8 \\
\hline $\mathrm{N} 2-\mathrm{C} 7$ & $5(6)$ & 1.242 & 1.264 & $\mathrm{C} 9-\mathrm{N} 1-\mathrm{C} 7-\mathrm{N} 2$ & (5) & -177.6 & 179.9 \\
\hline $\mathrm{C} 16-\mathrm{C} 1$ & (8) & 1.514 & 1.517 & $10-\mathrm{N} 1-\mathrm{C} 7-\mathrm{N} 2$ & (8) & -4.7 & -0.6 \\
\hline $\mathrm{C} 17-\mathrm{C} 18$ & $1.491(8)$ & 1.520 & 1.525 & $\mathrm{C} 9-\mathrm{N} 1-\mathrm{C} 7-\mathrm{S} 1$ & $-3.5(6)$ & 2.5 & -0.2 \\
\hline $\mathrm{C} 7-\mathrm{S} 1-$ & $92.2(3)$ & 92.3 & 91.9 & $10-\mathrm{N} 1-\mathrm{C} 7-\mathrm{S} 1$ & 171.2(4) & 175.3 & 179.3 \\
\hline $\mathrm{C} 9-\mathrm{N}$ & & & & $3-\mathrm{S} 1-\mathrm{C} 7-\mathrm{N} 2$ & & 178.7 & 178.7 \\
\hline $\mathrm{C} 9-\mathrm{N} 1-$ & $.6(4)$ & 120.7 & 120.8 & $\mathrm{C} 8-\mathrm{S} 1-\mathrm{C} 7-\mathrm{N} 1$ & $4.0(4)$ & -1.3 & -1.1 \\
\hline $\mathrm{C} 7-\mathrm{N} 1-\mathrm{C} 10$ & $.3(5)$ & 121.1 & 121.3 & $\mathrm{C} 7-\mathrm{S} 1-\mathrm{C} 8-\mathrm{C} 9$ & $-3.5(5)$ & -0.2 & 2.0 \\
\hline $\mathrm{C} 15-\mathrm{O}$ & & & & 7- $11-\mathrm{C} 9-\mathrm{O} 2$ & -179 & 178.1 & -178.0 \\
\hline $\mathrm{C} 1-\mathrm{O} 3-$ & & 121.7 & .8 & $10-\mathrm{N} 1-\mathrm{C} 9-\mathrm{O}$ & $6.1(9)$ & 5.1 & 2.5 \\
\hline $\mathrm{O} 3-\mathrm{C} 1-\mathrm{C} 2$ & $6(6)$ & 125.0 & 125.3 & $\mathrm{C} 7-\mathrm{N} 1-\mathrm{C} 9-\mathrm{C} 8$ & $0.8(7)$ & -2.5 & 1.7 \\
\hline $\mathrm{O} 3-\mathrm{C} 1-\mathrm{C} 6$ & & 115.7 & & $10-\mathrm{N} 1-\mathrm{C} 9-\mathrm{C} 8$ & $-173.9(5)$ & -175.4 & -177.7 \\
\hline $\mathrm{C} 5-\mathrm{C} 6-\mathrm{N} 2$ & $9(6)$ & 120.1 & 120.7 & $\mathrm{~S} 1-\mathrm{C} 8-\mathrm{C} 9-\mathrm{O} 2$ & $-177.8(5)$ & -179.2 & 177.3 \\
\hline $\mathrm{C} 1-\mathrm{C} 6-\mathrm{N} 2$ & & 120.3 & & $-\mathrm{C} 8-\mathrm{C} 9-\mathrm{N} 1$ & & 1.3 & -2.4 \\
\hline $\mathrm{C} 7-\mathrm{N} 2-\mathrm{C} 6$ & & 121.1 & 121.2 & $\mathrm{C} 9-\mathrm{N} 1-\mathrm{C} 10-\mathrm{C} 11$ & $-77.9(7)$ & -101.3 & -112.9 \\
\hline $\mathrm{N} 2-\mathrm{C} 7-\mathrm{N} 1$ & $121.4(5)$ & 122.3 & 122.4 & $\mathrm{C} 7-\mathrm{N} 1-\mathrm{C} 10-\mathrm{C} 11$ & $107.5(6)$ & 86.0 & 67.6 \\
\hline $\mathrm{N} 1-\mathrm{C} 7-\mathrm{S} 1$ & & 110.3 & & $\mathrm{C} 9-\mathrm{N} 1-\mathrm{C} 10-\mathrm{C} 15$ & & 78.4 & 66.9 \\
\hline $\mathrm{C} 9-\mathrm{C} 8-\mathrm{S} 1$ & & 107.8 & & $\mathrm{C} 7-\mathrm{N} 1-\mathrm{C} 10-\mathrm{C} 15$ & & -94.3 & -112.5 \\
\hline $\mathrm{O} 2-\mathrm{C} 9-\mathrm{N} 1$ & $126.0(5)$ & 125.0 & 125.0 & $\mathrm{~N} 1-\mathrm{C} 10-\mathrm{C} 11-\mathrm{C} 12$ & $178.2(5)$ & 179.5 & 179.1 \\
\hline $\mathrm{O} 2-\mathrm{C} 9-\mathrm{C} 8$ & & 123.2 & & $\mathrm{C} 16-\mathrm{O} 1-\mathrm{C} 15-\mathrm{C} 14$ & & 4.3 & 7.4 \\
\hline $\mathrm{N} 1-\mathrm{C} 9-\mathrm{C} 8$ & & 111.7 & 111.4 & $\mathrm{C} 16-\mathrm{O} 1-\mathrm{C} 15-\mathrm{C} 10$ & $177.0(5)$ & -175.9 & -173.2 \\
\hline $\mathrm{C} 11-\mathrm{C} 10-\mathrm{N} 1$ & $121.2(5)$ & 120.4 & 120.3 & $\mathrm{C} 13-\mathrm{C} 14-\mathrm{C} 15-\mathrm{O} 1$ & $178.4(5)$ & 179.5 & 178.4 \\
\hline $\mathrm{C} 15-\mathrm{C} 10-\mathrm{N} 1$ & $118.0(5)$ & 118.8 & 119.0 & $\mathrm{C} 11-\mathrm{C} 10-\mathrm{C} 15-\mathrm{O} 1$ & $-178.4(5)$ & -179.4 & -178.1 \\
\hline $\mathrm{O} 1-\mathrm{C} 15-\mathrm{C} 14$ & $126.1(6)$ & 124.9 & 124.8 & $\mathrm{~N} 1-\mathrm{C} 10-\mathrm{C} 15-\mathrm{O} 1$ & $2.6(7)$ & 0.8 & 2.1 \\
\hline $\mathrm{O} 1-\mathrm{C} 15-\mathrm{C} 10$ & $115.4(5)$ & 116.2 & 116.3 & $\mathrm{~N} 1-\mathrm{C} 10-\mathrm{C} 15-\mathrm{C} 14$ & $-177.3(5)$ & -179.3 & -178.4 \\
\hline $\mathrm{O} 1-\mathrm{C} 16-\mathrm{C} 19$ & $105.3(5)$ & 107.4 & 107.3 & $\mathrm{C} 15-\mathrm{O} 1-\mathrm{C} 16-\mathrm{C} 19$ & $-178.7(5)$ & 177.2 & 175.2 \\
\hline $\mathrm{O} 3-\mathrm{C} 17-\mathrm{C} 18$ & $108.4(6)$ & 112.5 & 112.7 & $\mathrm{C} 1-\mathrm{O} 3-\mathrm{C} 17-\mathrm{C} 18$ & $-176.1(5)$ & 82.3 & 80.1 \\
\hline
\end{tabular}

largest deviation between the X-ray data and theoretical calculations at the $\mathrm{HF} / 6-31 \mathrm{G}(d, p)$ level is around $0.08 \AA$ for distances and $2.7^{\circ}$ for bond angles. The $\mathrm{B} 3 \mathrm{LYP} / 6-31 \mathrm{G}(d, p)$ results deviate in the range from $0.002 \AA$ to $0.8 \AA$ for bond lengths, and from $0.03^{\circ}$ to $2.66^{\circ}$ for bond angles. The difference between the experimental and calculated bond lengths calculated at the HF level with $6-31 \mathrm{G}(d, p)$ basis set does not exceed $0.058 \AA$, whereas in the case of B3LYP with the same basis set, the largest difference between the observed and calculated values is about $0.05 \AA$. The bond angles for $\operatorname{HF} / 6-31 \mathrm{G}(d, p)$ calculations are very close to the experimental values (Table 1), and the maximum difference is about $2.5^{\circ}$. For DFT with the $6-31 \mathrm{G}(d, p)$ basis set, the bond angle difference does not exceed $3^{\circ}$. 
Geometry of the C-H... , C-H... $\mathrm{N}$ and $\mathrm{C}-\mathrm{H} . . \mathrm{S}$ H-bonds in I obtained by X-ray diffraction

\begin{tabular}{|c|c|c|c|c|c|c|c|c|c|}
\hline $\mathrm{D}-\mathrm{H} \ldots \mathrm{A}$ & $\mathrm{D}-\mathrm{H}$ & H...A & D...A & $\mathrm{D}-\mathrm{H} \ldots \mathrm{A}$ & $\mathrm{D}-\mathrm{H} \ldots \mathrm{A}$ & $\mathrm{D}-\mathrm{H}$ & H...A & D...A & $\mathrm{D}-\mathrm{H} \ldots \mathrm{A}$ \\
\hline $\mathrm{C} 5-\mathrm{H} 5 \ldots \mathrm{S} 1$ & 0.93 & 2.87 & $3.173(7)$ & 100.5 & $\mathrm{C} 11-\mathrm{H} 11 \ldots \mathrm{S} 1^{\mathrm{iii}}$ & 0.93 & 2.79 & $3.852(5)$ & 159.1 \\
\hline $\mathrm{C} 3-\mathrm{H} 3 \ldots \mathrm{O} 2^{\mathrm{i}}$ & 0.93 & 2.92 & $3.788(8)$ & 155.0 & $\mathrm{C} 12-\mathrm{H} 12 \ldots \mathrm{O} 2^{\mathrm{iv}}$ & 0.93 & 2.58 & $3.428(7)$ & 151.9 \\
\hline $\mathrm{C} 8-\mathrm{H} 8 \mathrm{~B} \ldots \mathrm{O} 3^{\mathrm{ii}}$ & 0.97 & 2.79 & $3.625(7)$ & 144.4 & $\mathrm{C} 16-\mathrm{H} 16 \mathrm{~A} \ldots \mathrm{O} 2^{\mathrm{v}}$ & 0.97 & 2.62 & $3.454(7)$ & 144.1 \\
\hline & & & & & $\mathrm{C} 17-\mathrm{H} 17 \mathrm{~B} \ldots \mathrm{N} 2^{\mathrm{vi}}$ & 0.97 & 2.90 & $3.635(7)$ & 133.3 \\
\hline
\end{tabular}

Symmetry codes: ${ }^{\mathrm{i}} x+1 / 2,-y+3 / 2, z-1 / 2 ;{ }^{\text {ii }}-x+1 / 2, y+1 / 2,-z+1 / 2 ;{ }^{\text {iii }}-x+1 / 2, y-1 / 2,-z+1 / 2$; ${ }^{\text {iv }}-x-1 / 2, y-1 / 2$, $-z+1 / 2 ;{ }^{\mathrm{v}}-x-1 / 2, y+1 / 2,-z+1 / 2 ;{ }^{\mathrm{vi}}-x,-y+1,-z$.

In summary, the optimized bond lengths and bond angles obtained using the DFT method are in good agreement with the corresponding X-ray structural parameters. It is worth noting that some of the optimized torsion angles have slightly different values from the corresponding experimental ones, due to the fact that the theoretical calculations consider only isolated molecules in the gas phase while the experimental results refer to molecules in the crystal environment.

Intermolecular H-bonds. The crystal structure exhibits intermolecular interactions of the $\mathrm{C}-\mathrm{H} \ldots \mathrm{O}, \mathrm{C}-\mathrm{H} \ldots \mathrm{N}$, and $\mathrm{C}-\mathrm{H} \ldots \mathrm{S}$ types, in which $\mathrm{C}$ atoms $(\mathrm{C} 3, \mathrm{C} 5, \mathrm{C} 8, \mathrm{C} 11, \mathrm{C} 12, \mathrm{C} 16$, and $\mathrm{C} 17)$ act as donors and $\mathrm{O}(\mathrm{O} 2$ and $\mathrm{O} 3), \mathrm{N} 2$, and $\mathrm{S} 1$ atoms act as acceptors. In the crystalline state, these intermolecular interactions stabilize the crystal structure. The geometry of the hydrogen bonded interactions is listed in Table 2. Fig. 5 shows some $\mathrm{H}$ bonds in the crystal.

\section{CONCLUSIONS}

In this study, we have synthesized the Z-3N(2-ethoxyphenyl)-2-N'(2-ethoxyphenyl)-iminothiazolidin-4-one compound (compound I), and its crystal structure was determined by single crystal $\mathrm{X}$-ray diffraction and a theoretical calculation. This compound belongs to the centrosymmetric space group $P 2_{1} / n$. The X-ray diffraction results were assessed by DFT and HF ab initio calculations with the $6-31 \mathrm{G}(d, p)$ basis set. The two computational methods gave very similar results, which are very close to those of X-ray measurements. The crystal structure is stabilized by $\mathrm{C}-\mathrm{H} \ldots \mathrm{O}, \mathrm{C}-\mathrm{H} \ldots \mathrm{N}$, and $\mathrm{C}-\mathrm{H}$...S type hydrogen bonds. The optimized geometrical parameters (B3LYP) are in agreement with those for the similar derivatives reported. Any discrepancy noted between the observed and calculated values can be due to the fact that the calculations were actually made for a single molecule in the gas phase contrary to the experimental values recorded in the solid state where the intermolecular Coulomb interactions are present. All the calculated and experimental data on the studied molecule are useful for the application in fundamental researches in chemistry and biology in the future.

We can also conclude that the chirality of this type of compound is evidenced by the high value of the dihedral angle $\left(79.7^{\circ}\right)$ formed by the heterocyclic ring and the aryl linked with the nitrogen atom. The chirality of compound $\mathbf{I}$ is induced by one of their 3-N-(2-alkyloxyaryl)-2thioxothiazolidin-4-one precursors, whose chirality in turn is due to the presence of a $\mathrm{C} 2$ axis of chirality.

In a forthcoming paper, we are going to present a spectroscopic study and other theoretical calculations on the same compound in order to evaluate the main physicochemical properties.

Fig. 5. View of two H-bonds in the crystal

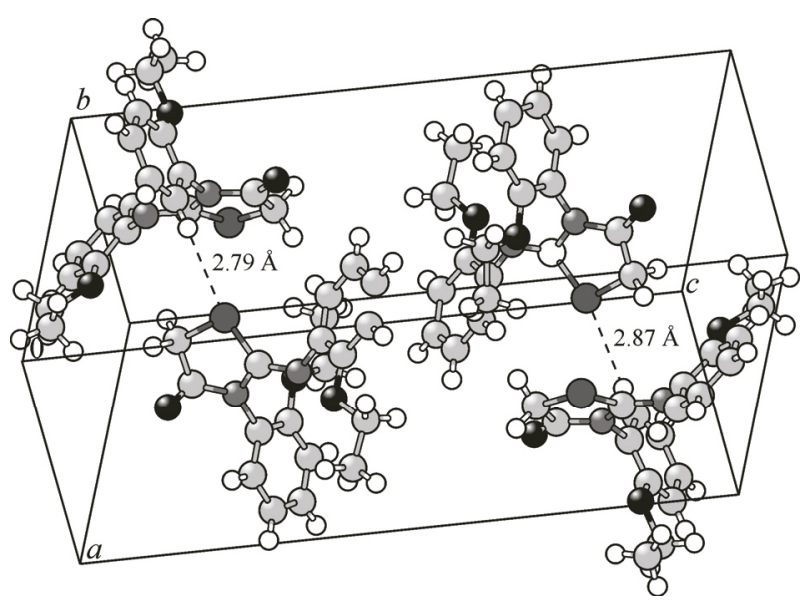


Crystallographic data for the structure reported in this article have been deposited with the Cambridge Crystallographic Data Center, CCDC 989101. Copies of this information may be obtained free of charge from the Director, CCDC, 12 Union Road, Cambridge, CBZ IEZ, UK. Facsimile (44) 01223 336 033, E-mail: deposit@ccdc.cam.ac.uk or http//www.ccdc.com.ac.uk/deposit.

\section{REFERENCES}

1. Saeed S., Rachid N., Jones P.G., Hussain R., Bhatti M.H. // Cent. Eur. J. Chem. - 2010. - 8, N 3. - P. 550.

2. Shokol T.V., Gorbulenko N.V., Turov A.V., Khilya V.P. // Chem. Heterocyclic Comp. - 2013. - 49, N 2. - P. 325.

3. Akhtar J., Hameed S., Al-Mosondi N.A., Khan K.M. // Heteroatom. Chem. - 2007. - 18, N 3. - P. 316.

4. Jamode V.S., Chandak H.S., Bhagat P.R. // J. Indian Chem. Soc. - 2008. - 85. - P. 1169.

5. Joshi S., Manikpuri A.D., Khare D. // J. Indian Chem. Soc. - 2008. - 85. - P. 508.

6. Haydon D.J., Collins I., Czapleurski L.G. // PCT Int Appl. WO. - 2009. - 37. - P. 485.

7. Smokal V., Derkowska B., Czaplicki R., Krupka O., Kolendo A., Sahraoui B. // Opt. Mater. - 2009. - 31. - P. 554.

8. Smokal V., Kolendo A., Derkowska B., Czaplicki R., Krupka O., Sahraoui B. // Mol. Cryst. Liquid Cryst. - 2008. - 485. - P. 1011.

9. Benhalima N., Toubal K., Chouaih A., Chita G., Maggi S., Djafri A., Hamzaoui F. // J. Chem. Crystallogr. - 2011. - 41. - P. 1729.

10. Toubal K., Djafri A., Chouaih A., Talbi A. // Molecules. - 2012. - 17. - P. 3501.

11. Sheldrick G.M. SHELXS-97 and SHELXL-97, Programs for Crystal Structure Refinement. - Univ. Göttingen, Germany, 1997.

12. Farrugia L.J. // J. Appl. Crystallogr. - 2012. - 45. - P. 849 - 854.

13. Wilson A.J.C. International tables for crystallography, vol. C. - Kluwer, Dordrecht, 1995.

14. Stewart R.F., Davidson E.R., Simpson W.T. // J. Chem. Phys. - 1965. - 42. - P. 3175.

15. Frisch M.J., Trucks G.W., Schlegel H.B., Scuseria G.E., Robb M.A., Cheeseman J.R., Montgomery J.A. Jr., Vreven T., Kudin K.N., Burant J.C., Millam J.M., Iyengar S.S., Tomasi J., Barone V., Mennucci B., Cossi M., Scalmani G., Rega N., Petersson G.A., Nakatsuji H., Hada M., Ehara M., Toyota K., Fukuda R., Hasegawa J., Ishida M., Nakajima T., Honda Y., Kitao O., Nakai H., Klene M., Li X., Knox J.E., Hratchian H.P., Cross J.B., Adamo C., Jaramillo J., Gomperts R., Stratmann R.E., Yazyev O., Austin A.J., Cammi R., Pomelli C., Ochterski J.W., Ayala P.Y., Morokuma K., Voth G.A., Salvador P., Dannenberg J.J., Zakrzewski V.G., Dapprich S., Daniels A.D., Strain M.C., Farkas O., Malick D.K., Rabuck A.D., Raghavachari K., Foresman J.B., Ortiz J.V., Cui Q., Baboul A.G., Clifford S., Cioslowski J., Stefanov B.B., Liu G., Liashenko A., Piskorz P., Komaromi I., Martin R.L., Fox D.J., Keith T., Al-Laham M.A., Peng C.Y., Nanayakkara A., Challacombe M., Gill P.M.W., Johnson B., Chen W., Wong M.W., Gonzalez C., Pople J.A. Gaussian 03, Revision B03, Gaussian Inc., Pittsburgh PA, 2003.

16. Frisch A.E., Nielsen A.B., Holder A.J. Gaussview. Gaussian Inc., Pittsburg, PA, 2003.

17. Becke A.D. // J. Chem. Phys. - 1997. - 107. - P. 8554.

18. Rauhut G., Pulay P. // J. Phys. Chem. - 1995. - 99. - P. 3093.

19. Cohen H.D., Roothaan C.C. // J. Chem. Phys. - 1965. - 43. - P. S34.

20. Fletcher R., Powell M.J.D. // Comput. J. - 1963. - 6. - P. 163.

21. Bader R.F. Atoms in molecules. A quantum theory. - Oxford: Clarendon Press, 1990. 